\title{
An Agent-Based Model as a Tool of Planning at a Sub-regional Scale
}

\author{
Fernando Pereira da Fonseca ${ }^{1}$, Rui A.R. Ramos ${ }^{1}$, \\ and Antônio Nélson Rodrigues da Silva ${ }^{2}$ \\ ${ }^{1}$ Department of Civil Engineering \\ University of Minho \\ Braga, Portugal \\ ffonseka@gmail.com, rui.ramos@civil.uminho.pt \\ ${ }^{2}$ Department of Transportation Engineering \\ School of Engineering of São Carlos \\ University of São Paulo \\ São Carlos, Brazil \\ anelson@sc.usp.br
}

\begin{abstract}
This paper describes an agent-based model developed to simulate the impact that different planning policies may have in enhancing the attractiveness of the industrial estates located in a network of four municipalities located in the North of Portugal. The policies were simulated using three scenarios that can be distinguished by the municipal level of coordination they are implemented and by the type of action performed. In the model, enterprises are agents looking for a suitable location and the estates attractiveness is based on their level of facilities, amenities, accessibility and in the cost of soil. The coordinated qualification of the industrial estates is the most effective policy to strengthen their attractiveness. It was in this scenario that more industrial estates become attractive and more enterprises relocated. Results also indicate that the promotion of diffused and unqualified industrial estates is an inefficient policy to attract enterprises.
\end{abstract}

Keywords: Agent-based models, Industrial estates, Planning, Territory.

\section{Introduction}

One of the main obstacles faced by the territorial planning is the difficulty in conciliate the expectations and interests of a large number of actors with the limited nature of the own territory. To address these challenges, the use of more robust tools has been conceived as a way to deal with the increasing levels of uncertainty and complexity related with the territory. The agent-based models (ABM) have emerged as a tool with potential to deal with these phenomena. In fact, ABM have been used to study many issues, such as traffic, accessibility, urban growth, suburbanisation, gentrification, segregation, etc. When compared with other more conventional tools of spatial analysis, such as the geographic information systems (GIS), and even with 
more advanced tools, such as cellular automata, the ABM have a number of advantages. They can represent the heterogeneity of the territorial actors, because each agent can represent the behaviour of each actor. They are based on a bottom-up approach, that is, the macro trends result from a variety of interactions kept at an individual level. They are dynamic because the agents have the ability to move around the environment, simulating the actors and the objects behaviour and to simulate the evolution of a phenomenon over time.

In this context, the aim of the paper is to present an ABM developed to simulate the impact that different policies may have in enhancing the attractiveness of the industrial estates located in a network of four municipalities located in the north of Portugal (Quadrilátero). The main goal of this network is to improve the competitiveness and the internationalisation of the territory, by acting in some critical sectors. One of them is the adoption of common actions to strengthen the capacity of the industrial estates for attracting enterprises, mainly by implementing planning policies. Inspired by this agenda, policies were simulated in the model using the three following scenarios: 1) maintenance of an uncoordinated and unqualified policy by the municipalities; 2) adoption of a coordinated policy of qualification of all the industrial estates; 3 ) impact of the strategies predicted by the municipalities in a scenario of: uncoordinated and low qualification (3a); and of coordinated and advanced qualification ( $3 b)$. The model was also developed to validate four hypotheses related with the implications of the policies in the estates' performance. These hypotheses are described with more detail in the Methodology Section.

Besides the introduction, the paper is composed by four main Sections. The first one comprises a theoretical framework of the subjects under analysis, with a focus on the ABM that use enterprises as the main topic of the study. The methodological approach and the main steps followed to construct the model are described in the second Section. The results and the main findings obtained with the model are discussed in the third Section, which is followed by the conclusions and some final remarks. Besides the findings obtained, this study is also an attempt to strength the literature in the industrial estates planning domain at a sub-regional scale, a topic scarcely exploited in the literature $[1,2,3]$.

\section{Modelling Enterprises: A Review}

Agent-based modelling is a form of computational simulation [4]. These models can be used to study a great diversity of urban and territorial phenomena, being the location one of the topics more analysed. The location is a problem that involves many entities (inhabitants, enterprises, public administration, real estates, etc.) which try to reply to the basic question: where should I locate? In fact, the location decision arises from a complex process, where individual aspects are articulated with economic, social and political factors [5]. On the other hand, there is a strong competition between the territories to attract resources, mainly those that produce more returns. Enterprises always have been central in the location models, since they generate jobs, revenues, taxes, traffic and can influent the transformation of soil, the 
location of residential areas and the attraction of more investments and enterprises. The model conceived by Alfred Webber in 1909 is a reference on the industrial location theories. The main goal of his model was to determine the optimal location for an industry, assuming that transport costs are a function of the euclidean distances between the sources of raw materials and the markets. This theory knew a remarkable expansion and inspired other studies. August Lösch gave a new emphasis to the location theory through the principle of the profit maximisation, considering a larger scale (the economic regions). In the second half of the last century, the behavioural theories gained more importance, being the approaches of Edgar Hoover, Walter Isard and Melvin Greenhut good examples of this new conception. The location only based in economic purposes is replaced by the principle that the best location is one that satisfies the particular requirements of entrepreneurs in a more efficient way. The selection becomes a probabilistic process where the individual preferences and motivations have an important role. In the last decades of the 20th century, the integrated or relational approach emerged [6]. This new conception takes in consideration both the economic and the behavioural aspects in the industrial location. The theory advocates that there is a strong interaction between an entrepreneur and the possible locations through a negotiating process. In this case, the territory with more suitable conditions that respond to the requirements of the entrepreneur will be the selected.

Enterprises also played a significant importance in the integrated land use and transportation models developed in the second half of the last century. The gravitational models were the first generation of these integrated models [7]. The cities were conceived as a system composed by several interacting areas in a continuous equilibrium condition. The goal of these models is, through mathematical equations (linear regressions), to predict the movements between the different sectors of a city, namely between the residential areas and the zones where the economic activities are located [8]. There are several examples of these interacting models based in spatial aggregation such as METROPOLIS TOMM, PLUM, ITLUP and IRPUD [9]. The IRPUD was one of the most complex working as macroanalytic model of economic and demographic change, composed by interlinked submodels that deal with relocation of enterprises, change of job, change of residence, etc. In the 1980's emerged a new generation of integrated models: the utility-maximising multinomial logit based models [7]. The spatial interaction of the first generation was replaced by logistic regression techniques that allows the prediction of events based in a set of observations. In comparison with the gravitational, these models are more integrated (they combine modules of land use and transportation) and more dynamic (the transportation module predicts the demand and its suitability while the land use module analyses the spatial distribution of residential areas and those that influence the employment, namely the industrial and the commercial areas [10]. The interaction between the modules of land use/transportation determines how transportation affects land use, which influences the location of activities and the traffic generation. There are several examples of these multinomial logit based models, such as MUSSA (predicts the location of households and enterprises), URBANSIM (integrates a household and economic mobility models to simulate whether households and 
enterprises decide whether to move) and the IMREL (integrated model of residential and employment location). In the beginning of this century, plans have incorporated micro-simulation methods. This new generation have notable differences when compared with the previous generations: they are more dynamic in the spatial and temporal dimensions; they use individual data in the simulation (objects, vehicles, parcels, etc.); the spatial interaction between the different parts of a territory are replaced by the interactions that arise from the interactions between the individual elements; and they conceived the territory in a condition of disequilibrium, due to the continuous changes operated by the actors over time [8], [11, 12]. This third generation was expanded through the development of two main tools: the cellular automata and the ABM [8]. The agent-based modelling is considered more powerful than the cellular automata, because they are more flexible and suitable to represent and simulate the individual behaviour and the territorial dynamics [11], [13, 14].

The ABM have had a large utilisation in the planning domain in the last two decades [15]. The applications encompass topics such as the urban grow [16], suburbanisation [17], gentrification [18], residential segregation [19, 20], accessibility [21], the impact of urban policies [22], the land use change [22, 23], the evolution of urban networks [24], among many others.

In the context of the ABM, enterprises usually appear as one of the agents simulated. A first selection can be made between the ABM that encompass many typologies of agents (inhabitants, households, dwellers, enterprises, public administration, etc.) from the models that only integrate enterprises in the modelling. In the first case enterprises are usually one of the entities simulated due to their implication in urban development, soil demand, location of residential areas and in traffic generation [7]. These generic models are composed by a changeable number of modules, one for each agent simulated. The enterprises' module controls the way these agents interact among them and with the remaining agents. There are several examples of these models, such as the Ilute [22] and ILUMASS [25]. The second category integrates models that can be grouped into three main topics: (i) to analyse the relationships between enterprises; (ii) the firmographic models; (iii) and the location models. The models developed to analyse the relationships between enterprises, namely in territories with a high concentration of enterprises (industrial districts and clusters) are the most representative. The relationships comprise variable domains: the concentration benefits achieved by the enterprises [26, 27]; the multiple forms of cooperative and competitive relationships that can be found is these areas [28]; how social phenomena may affect clusters' dynamics [29]; and how innovation propagates among the enterprises [30]. In turn, the firmographic models are focused in identify scenarios related with the enterprises' evolution in a specific territory, not only in terms of birth, grow and death, but also their implications in terms of jobs, urban development, mobility and to anticipate the location and the relocation decisions of the enterprises [2], [31]. There are several firmographic models, such as the models developed by Khan [1], Wissen [32] and by De Bok [33]. The last category is the less exploited in the literature and comprises the approaches carry out to find a suitable location for a specific enterprise or industrial sector. The ABLOOM model [34] and the work of Manzato et al. [35] are two examples of simulations 
developed with this specific intent. In other type of applications, ABM have been used to improve the productive and the organizational processes at the individual scale of the enterprises [36].

In this global framework, we present in the next Sections the main steps undertaken to develop an ABM that use enterprises to assess the impact of some policies in the attractiveness of industrial estates. In the literature we hadn't found an identical approach, which highlights the innovator character of this study.

\section{$3 \quad$ Methodology}

The implementation of the model followed several sequential steps. The first one was the acquisition of data. As the initial purpose was the construction of a spatially explicit model, the first step was the acquisition of detailed data about the industrial estates and with the industrial enterprises. The industrial estates data was gathered through a survey addressed to the municipal services with the aim of collecting information about their location and their general characteristics (surfaces, number of plots, number of enterprises installed, price by $\mathrm{m}^{2}$, etc.). Further, the survey intended to identify the coverage of 16 facilities and 14 amenities in each industrial estate. Furthermore, the survey included some questions to disclose the strategies predicted by the municipalities, namely to understand whether the existing supply would be enlarged in the future through the creation of new estates or through the expansion of the existing ones. As the data collected with the surveys had several gaps, all the industrial estates identified by the municipalities were visited in order to obtain the missing data and to check all the information provided. During this fieldwork, the business owners located in the industrial estates were also interviewed. The goal of this survey was to learn about the past and future locative behaviour of the entrepreneurs and their satisfaction level regarding the provided conditions. The data obtained with this survey was helpful to calibrate the model. In short, the survey showed that the majority of enterprises located in the industrial estates come from a diffuse situation (88\%), having predominantly micro and small size (78\%). Moreover, the survey indicated that $90 \%$ of the entrepreneurs are reasonably satisfied with the conditions provided and, for that reason, they were not interested in moving to another industrial estate.

In the case of the enterprises, the data used was the Integrated Business Accounts System (SP 2011). This is a data base compiled by the Portugal Statistics that contain disaggregated data about enterprises, including location, sectors of activity, number of employees, turnover, etc. Based on the location provided in the database, all the enterprises and their attributes where mapped through points using the ArcGis software.

Once the data collection was conclude, the next step was the definition of the rules that control how the model run. To accomplish the model intentions, the definition of the industrial estates attractiveness was the starting point of this task. Following the recommendations of Bodenmann and Axhausen [38], the attractiveness was based on the level of facilities, amenities, accessibility and on the land cost in each industrial 
estate. Based on the presence (1) or on the lack (0) of the different facilities and amenities, the respective coverage (in percentage) was estimated for each industrial estate according the formulas presented in the Table I. The criteria proposed by Ramos and Mendes [39] were used to estimate the accessibility of each industrial estates to five transportation infrastructures (national road, motorway intersection, railroad terminal, seaport and airport). Thus, the accessibility of an estate can be classified as excellent $(\leq \mathrm{D}(\mathrm{Dmax} / 2)$, acceptable $(\mathrm{Dmax} \leq \mathrm{D}<(\mathrm{Dmax} / 2)$ or bad $(\mathrm{D}$ $>$ Dmax $)$. Based on this classification different weights were assigned to each estate ( 1 = excellent; $0.5=$ acceptable; $0=$ bad) through which their final accessibility (in percentage) according to the formula presented in the Table I. Regarding costs, several variables were pondered, but in the end only the cost of land was included, considering the average price identified in each estate. In fact, the fieldwork showed that the labour and the utilities costs were identical due to the subregional scale of the study. Further, the land cost was the variable most difficult to identify due its strong variation from plot to plot and to the presence of several owners/promoters in each estate.

In the model, enterprises have the ability to move and relocate whenever an attractive estate is found. However, relocation is not a random process. Inspired on the conclusions obtained with the survey, relocation follows criteria related with the enterprises' size, location and distance (to an industrial estate). Since the supply is targeted for small enterprises, it was stipulated that only the small and the micro enterprises can relocate in an estate. From the locative point of view, the relocating enterprises are those with a diffuse location with bad (0) coverage in terms of accessibility and of facilities and amenities. In scenario 1, the relocating enterprises were those with bad coverage in the three locative criteria described (258), but in the scenarios 2 and 3, due to the larger supply simulated, the relocating enterprises encompass all that had a bad performance in two of those criteria (1145). Since the facilities and amenities coverage in the area of the diffuse enterprises was unknown, it was assumed that enterprises located in rural areas and predominantly rural spaces would have a worse coverage (0) than those located in urban areas (1). The distinction between the urban and the rural spaces was made through the Classification of Urban Areas published by the Portugal Statistics at the statistical subsection unity (the most disaggregated available). Finally, the maximum range of relocation of an enterprise was set at $20 \mathrm{~km}$. This criterion was introduced because the survey showed that most relocations occur in the same municipality.

Table 1. Procedures used in the evaluation of the industrial estates attractiveness

\begin{tabular}{|l|l|}
\hline Facilities & Amenities \\
\hline$R_{\text {Inf }}=\left(\frac{\sum(\text { Faci }) \times 100}{16}\right)$ & $R_{\text {Ament }}=\left(\frac{\sum(\text { Ameni }) \times 100}{14}\right.$ \\
\hline Accessibility & Land cost \\
\hline$R_{\text {Acess }}=\left(\frac{\sum(\text { Access }) \times 100}{5}\right.$ & \multirow{2}{*}{$\mathrm{L}_{\mathrm{c}}=\overline{\mathrm{X}}_{\mathrm{AAE}}$} \\
\hline
\end{tabular}


After concluding the theoretical procedures of the model, the next step was the selection of a suitable toolkit to simulate the described phenomenon. After the evaluation of several options, the NetLogo toolkit was chosen mostly because NetLogo has a GIS extension that supports vector data in the form of ArcGis shapefiles, where all the geographic information was initially processed. Due to the NetLogo characteristics, the patches (cells in which the environment is divided) were used to represent the industrial estates while the enterprises were the agents of the model. Each industrial estate was represented by a changeable number of patches, which contain information about the facilities, the amenities, the accessibility and the cost of soil. The model was developed with many buttons and commands to optimise the simulation process.

In the relocation process, enterprises interact with patches looking for a better location. The relocation only occurs if the new place represents an improvement of the conditions experienced by the diffused enterprises and if the estate has vacant plots. The locative conditions are determined by the combination of the four parameters mentioned above (facilities, amenities, accessibility and cost of soil), having as reference the average values obtained in the four municipalities. The attractiveness of an industrial estate is defined by minimum values that are changeable according to the scenario simulated (Table II). Each scenario correspond to a different policy. For instance, the qualification of the industrial estates was achieved through an improvement of the facilities, amenities and, occasionally, of the accessibility values. The improvement induced in those parameters arise not only from the inclusion of some basic facilities and amenities that were missing in some estates, but also from the inclusion of more advanced infrastructures and services. With the enhancement of the general conditions offered by the estates, it was assumed that the locative requirements of enterprises would also be higher. To avoid the exclusion of industrial estates without vacant plots from the simulation, in scenarios 2 and 3 a fictional number of vacant plots was attributed to those estates. In the model, enterprises do not have pre-defined preferences for any industrial estate or for any municipality and can move to any one of them according to the established criteria. In the relocation process, when an enterprise settles on an industrial estate, a vacant plot was deducted, ending the process when all the vacant plots are occupied by enterprises.

Table 2. Minimum locative requirements considered in the enterprises relocation

\begin{tabular}{|c|c|c|c|c|c|}
\hline \multicolumn{2}{|c|}{ Scenarios } & Facilities & Amenities & Accessibilities & $\operatorname{Cost}\left(€ / \mathrm{m}^{2}\right)$ \\
\hline \multicolumn{2}{|l|}{1} & $\geq 54,6 \%$ & $\geq 19,9 \%$ & $\geq 56,8 \%$ & \multirow{4}{*}{$<733$} \\
\hline \multicolumn{2}{|l|}{2} & $\geq 73,2 \%$ & $\geq 42,4 \%$ & $\geq 58,9 \%$ & \\
\hline \multirow{2}{*}{3} & $3 \mathrm{a}$ & $\geq 50,1 \%$ & $\geq 18,6 \%$ & $\geq 58,2 \%$ & \\
\hline & $3 b$ & $\geq 61,4 \%$ & $\geq 30,1 \%$ & $\geq 58,2 \%$ & \\
\hline
\end{tabular}

\section{$4 \quad$ Case Study}

The model was performed to the Quadrilátero, designation given to a network of four municipalities (Barcelos, Braga, Guimarães and Vila Nova de Famalicão) located in 
the North of Portugal. This territory has a strategic location due to the proximity of the Oporto Metropolitan Area and has a good accessibility and proximity to several transportation and logistics facilities located in the region (airport, seaport, railroad terminal, logistic platforms, etc.). According with the last census [40], the Quadrilátero has 593.841 inhabitant's, being 39\% urban residents, mainly in Braga, the biggest urban centre in the region. Despite the bigger importance of services in jobs, $45 \%$ of the active people works in secondary activities mainly in the 4722 industries located in this territory [40]. In fact, the Quadrilátero is an old industrial area. In the second half of the 20th century, manufacturing knew a great development in the region, mainly due to the establishment of textile and clothing industries. However and since the 1990s, the region where the Quadrilátero is inserted experienced an industrial crisis with the exit of several enterprises. As Barbot [41] highlights, competition from East European and Asian countries may have been one of the leading factors of the crisis, together with a wage raise due to a shortage in the labour offer. Gross investments were spent and several studies and plans were made to rehabilitate the declining sectors. Despite the fall detected in some sectors and in the employment, the region experienced some recovery through the development of trade and services and to a small but increasing industrial diversification and modernisation of the traditional sectors. The last decade was distinguished by the emergence of new sectors, based on technology, innovation and knowledge, being very competitive in the international context. This include software, nanotechnologies, health, electronic and optic, among others. Even the traditional sectors have slowly move to a pattern based on quality, design and innovation. As a consequence, the Quadrilátero have installed enterprises that occupies the first position in the Portuguese ranking considering the turnover in many industrial sectors, namely in textile, clothing, leathery, rubber (tyres production) and electrical and optical components. The global turnover achieved by the industrial enterprises located in the Quadrilátero was $5500 \mathrm{M} €$ in 2010 [37]. The Quadrilátero trade balance is also very favourable (1800 M€) which attests the productive capacity of the industries located in this territory.

Recognising this potential, local entities decided to constitute a network among the four municipalities in order to exploit in a more efficient way their common potentialities. The goal is to improve the competitiveness and the internationalisation of the territory by acting in some critical points. One of them intends to turn the industrial estates more attractive to enterprises by adopting common planning practises, by the qualification of the spaces and by the adoption of a common management structure for all the estates. The model was developed to give some insights to the impact that the adoption of some policies in a coordinate manner by the four municipalities, namely in terms of the estates' qualification, can play in their attractiveness. In the Section VI we present the results of that simulations.

\section{$5 \quad$ Main Features of the Industrial Estates}

In this Section, the main features of the industrial estates located in the Quadrilátero are described according with the data collected with the surveys. These four 
municipalities have 79 industrial estates (Fig. 1) in two different categories: the planned areas (51 estates) and the spontaneous spaces which become of industrial use by the concentration of several enterprises in these areas (28 estates). The 79 industrial estates occupy a global surface of 1440 ha, being 20 ha areas of expansion (without occupation). Guimarães is the municipality with more industrial soil (569 ha) while Barcelos provides the smallest surface (107 ha). These spaces are strongly diffused by the municipal territories and are mostly of small and medium dimension (50\% have less than 10 hectares of global surface and only one estate have more than 100 hectares).

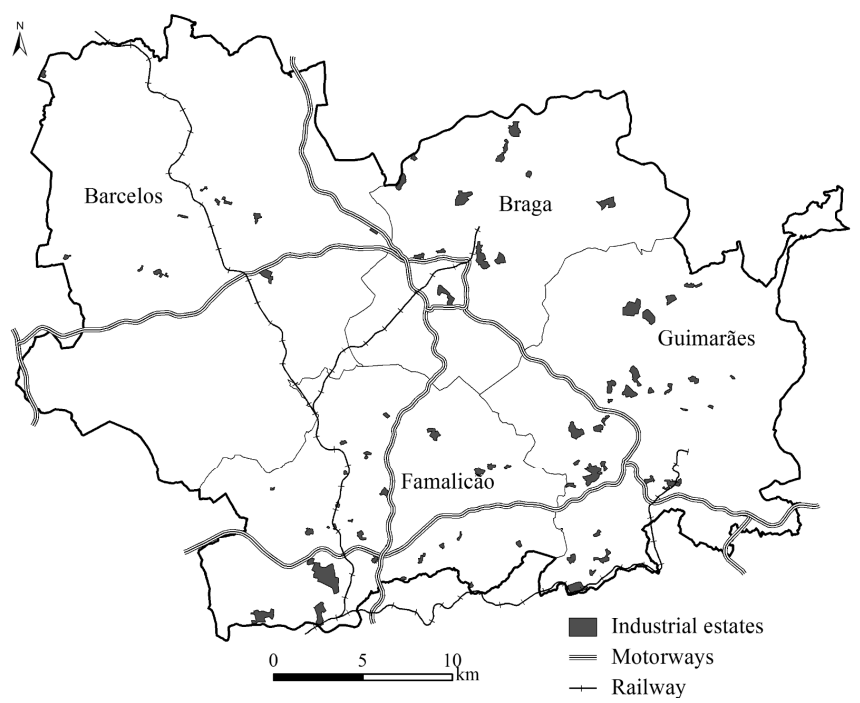

Fig. 1. The industrial estates location in the Quadrilátero

The 79 estates are subdivided in 2404 lots with widely varying dimensions. In 2012, when the survey was made, 639 of these lots were vacant. This problem affected particularly the estates located in Guimarães, where 36\% of them were unoccupied. The land cost is also strongly variable from estate to estate, being the most difficult variable to estimate, due to the private nature of almost all the parks. In several situations, the land cost does not have correspondence with the facilities and with the amenities installed in some estates. The strong differences diagnosed in the prices arises from objective reasons related with the conditions offered by the estates (modern buildings, the location, advanced facilities, etc.), but also depends from the individual management made by each owner/promoter (financial and speculative purposes).

Regarding the facilities and the amenities, the industrial estates have a globally poor coverage. From the 16 facilities considered in the survey, only four were identified in the 79 estates (parking, internal roads, telecommunications and electricity supply). The most advanced facilities in a technological and in an environmental point of view (natural gas, optical fibre and wastewater treatment 
plant) are only present in a few numbers of parks. The coverage by amenities is even worst since many of the 14 services considered in the study were not installed in many estates, such as post office, service station, bank and multifunctional buildings. However some of these amenities can be found in the adjacent urban areas, performing a proximity service to the entrepreneurs located in the industrial estates. The diagnosis also demonstrated that the 28 spontaneous spaces have worst coverage by facilities and amenities than the planned areas.

In other hand, the accessibility is favourable. The industrial estates are located in a distance of $1.8 \mathrm{~km}$ from a main road and in a distance of $5.7 \mathrm{~km}$ from a motorway intersection. However, it was found that 14 industrial estates have particularly bad accesses, staying away from the convenient distances proposed by Ramos and Mendes [39]. The most critical situations appear in Guimarães, where the territorial diffusion of the parks is particularly high.

The strategies disclosed by the municipalities in 2012 does not revealed any level of integration, being in completely disagreement with the national and the regional guidelines for these spaces. The policies addressed by the municipalities include the expansion of 11 existing estates and the creation of five new parks. Both, these actions will increase in 435 hectares de supply of industrial soil in the Quadrilátero. If we take in consideration that the existing estates already have a substantial area of expansion (220 hectares), the implementation of the predict strategies will augment significantly the offer of industrial soil. Despite being questionable if the territory needs so many industrial soil, the policies predicted insist in the same mistakes undertaken in the past. Thus, they will contribute to widespread the estates by the municipal territories without any purpose of territorial coherence and without physical and functional articulation with the estates located in the neighbour municipalities (including those from Quadrilátero). The promotion of new estates in peripheral areas will probably create more spaces with low levels of coverage by facilities and amenities and can worsen some problems, namely the number of vacant lots and the declining of some parks (the less attractive). The simulation will confirm or not this suspicions.

In relation to the enterprises (Fig. 2), the Quadrilátero had 4722 industries located in his territory (INE, 2011). The greatest part of these enterprises were not located in an industrial estate $(82 \%)$ and most of them $(93 \%)$ were small or micro enterprises. The industries of the Quadrilátero generated a turnover of $5495 \mathrm{M} €$ and an international commerce (exportations) of $2772 \mathrm{M} €$ (INE, 2010). In the industrial estates were located 873 industries, being predominantly micro and small enterprises. The number of companies installed in these parks was very variable (between three and more than 40).

The turnover generated by each estate is also very different. For instance, the turnover produced in the industrial estate of Lousado (Famalicão) is bigger than the turnover generated by all the enterprises located in the 11 estates of Barcelos. This is related with the dimension of the enterprises and with the industrial sectors presented in each park. In the estates of Barcelos and Guimarães the most relevant sectors are the clothing and textile; in Braga is the metallurgic and the metalomecanic industries; while in Famalicão, despite the clothing, the rubber and the food sectors are also well represented. 
The survey addressed to the entrepreneurs located in the industrial estates gave some relevant data, which was used to calibrate the model. The survey showed that $92 \%$ of the enterprises came from a diffuse location. The relocation was explained by several reasons, being the most relevant the following: the existence of an available area in the estates, the geographical location and the accessibility of the parks. In other hand, the majority of respondents $(90 \%)$ does not intend to relocate to another estate. Indeed, entrepreneurs make a satisfactory evaluation of the conditions offered by the estates ( 3.3 on a scale of 5). The most criticised aspect was the quality and the low diversity of the amenities presented in the estates (this component received an evaluation of 2.3). In the other side, the most valued component was the good atmosphere and the good relations between the enterprises located in the estates (3.8).

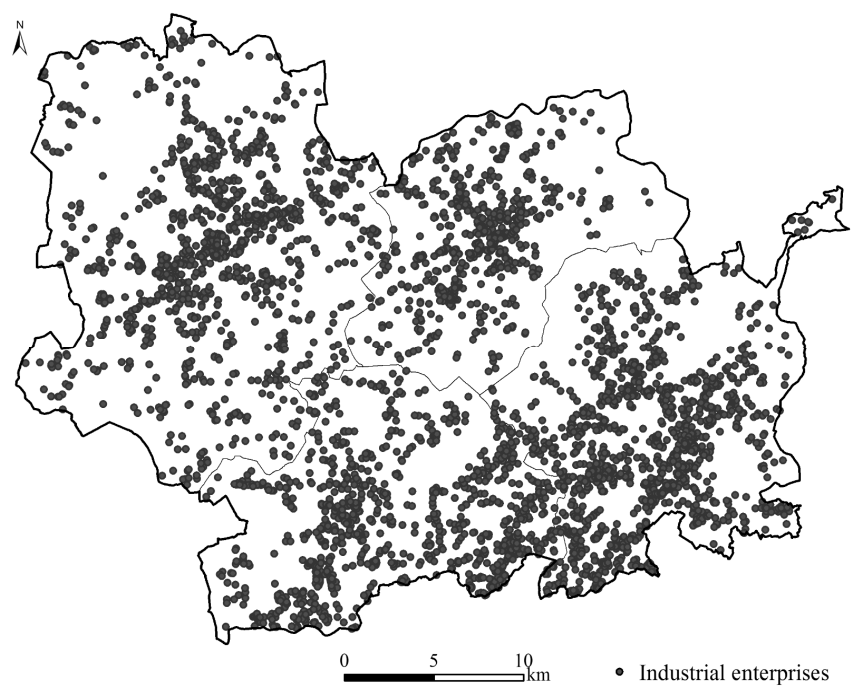

Fig. 2. Geographic distribution of the enterprises in the Quadrilátero

The findings obtained with the diagnosis and with the survey were useful to define the model and its rules. The main goal was to identify which policies may be useful to overcome the problems identified and to turn the industrial estates more competitive and attractive in a regional scale. The results of this simulation are described in the next Section.

\section{Results and Discussion}

This Section summarises the results obtained with the model. According with the methodology described in the Section III, the data related with the industrial estates and the enterprises was imported from the ArcGis to the NetLogo with several attributes necessary to the simulation. The simulation environment is represented in the Fig. 3. 
As described in the Introduction, the model was performed to test the effect of the following three scenarios on the attractiveness of industrial estates: 1) maintenance of an uncoordinated and unqualified policy by the municipalities; 2) adoption of a coordinated policy of qualification of all the industrial estates; 3) impact of the strategies predicted by the municipalities in a scenario of: uncoordinated and low qualification (3a); and of coordinated and advanced qualification (3b). Further, the model was used to validate four hypotheses related with the impact of those policies on industrial estates. The envisaged hypotheses were the following: 1) the coordinated policies increase the attractiveness of all the industrial estates; 2) the coordinated policies leads to a common pattern of the estates occupancy in all municipalities; 3) a qualification policy improves the occupancy rate of all estates; 4) the promotion of diffused estates with low levels of qualification is an inefficient policy to attract enterprises. The following discussion will be focused on the impact of the scenarios in the attractiveness of industrial estates and in the validation of the hypotheses described.

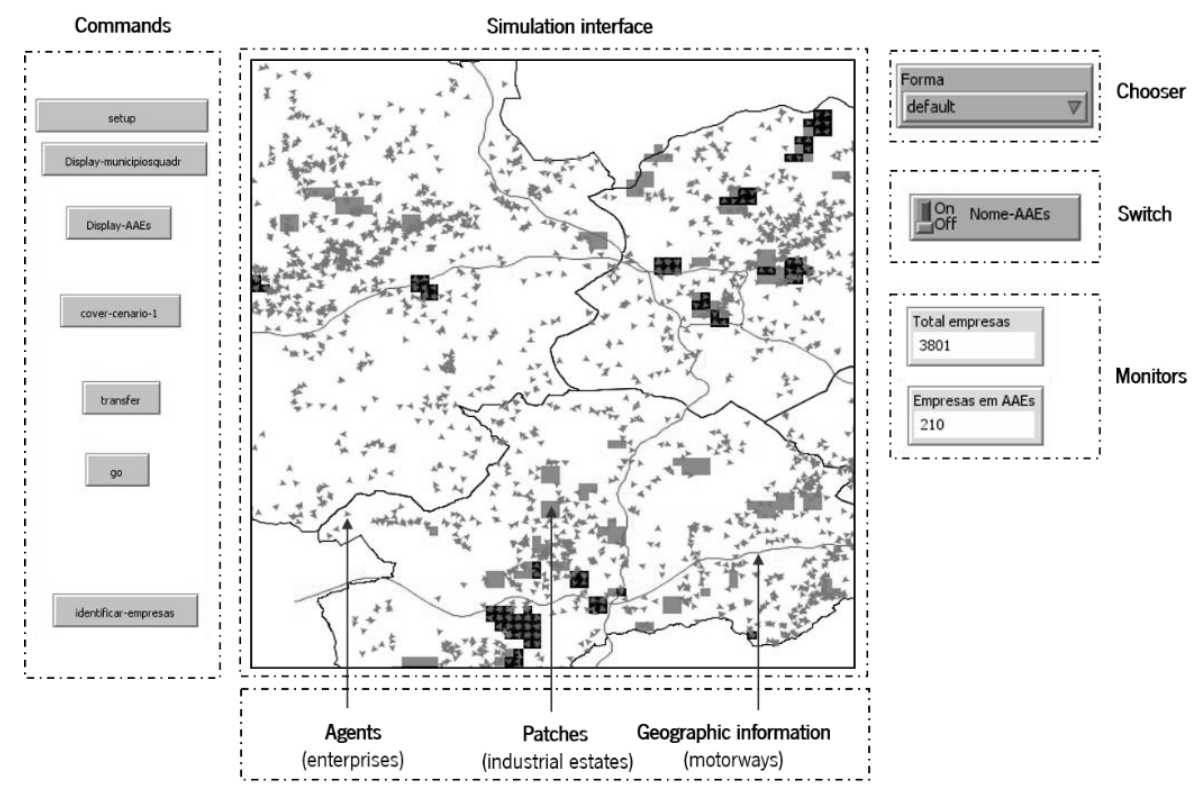

Fig. 3. Partial view of the model developed in the NetLogo toolkit

Despite the low level of locative requirements given to the enterprises in the scenario 1 (which represents the current situation and the starting point of the simulation), the results show that most of the industrial estates remain unattractive to enterprises (Table III). In fact, the lowest number of relocated enterprises was attained in this scenario (235) and 404 of the available plots remain vacant after the simulation (37\% of the available supply). From the 79 industrial estates only 24 were attractive to enterprises. This bad performance is explained by the very low level of amenities 
found in many estates (19.9\% on average) and by the lack of many basic facilities and by the poor accessibility diagnosed in many estates. During last years, municipal policies worsened this problem by encouraging the diffusion of a significant number of small estates with low levels of qualification by the municipal territories.

The impact of a coordinated qualification was tested in the scenarios 2 (existing estates) and $3 b$ (where the predicted estates were included). The results show that this policy has a positive impact in the attractiveness of industrial estates. Regarding the existing estates, the comparison with the results obtained in the scenario 1 (Table III) indicates that there are more attractive industrial estates $(+26)$, the number of relocated enterprises more than doubled and the number of vacant plots was substantially lower (-291). In the case of the scenarios that include the predicted strategies ( $3 \mathrm{a}$ and $3 \mathrm{~b}$ ), the simulation indicated that the most efficient policy is the provision of qualified estates. In fact, in scenario $3 \mathrm{~b}$ the number of relocated enterprises is considerably higher $(+223)$ and the number of vacant plots decreases proportionally (from 917 to 694). These results clearly demonstrate that qualification is an important policy to improve the capability of industrial estates attract enterprises. Nonetheless, these results only partially validate hypothesis 3 . The qualification policy improves the occupancy rate of the estates, but many remain vacant. In fact, in the scenarios 2 and $3 \mathrm{~b}$ many estates remain unattractive even if qualified. This is related with structural deficiencies that arise from the location defined for those industrial estates.

The implementation of coordinate policies between the municipalities can be more efficient in the locative performance of the industrial estates than if municipalities pursue with their individual initiatives. Results showed that both in the cases of the existing estates as well as in the case of the predicted sites, coordination improves the number of attractive estates (except in the scenario $3 b$ ) and the number of relocated enterprises (more 291 in the scenario 2 and more 223 in the case of the scenario 3b).These benefits are extensive to all municipalities, especially those where accessibility is more favourable. Thus, the results show that a coordinated policy has a global positive impact on the capability of industrial estates attract enterprises. However, these results only partially validate the hypothesis 1 . The implementation of coordinated policies enhance the locative performance of many estates, but a significant number of them remain unattractive (Table III). On the other hand, results do not validate the hypothesis 2 . Policies coordination does not produce an identical pattern of the industrial estates occupancy at the municipal level. In fact, at the Quadrilátero level and even at the internal scale of each municipality there are industrial estates with very different locative conditions. The most affected are the municipalities with more problems of accessibility and those which encourage the territorial diffusion of the estates. In this context, Guimarães emerge as the municipality where these problems are more visible and where the impact of these policies is less effective. On the other hand results indicate that municipalities with estates less diffused (which are usually the more attractive) are the most benefited by the adoption of coordinated policies. This is the case of Famalicão and Braga.

Considering the attractiveness of industrial estates, the model demonstrated that the adoption of a coordinated policy of qualification produces different municipal. The 
comparison of the scenarios $3 \mathrm{a}$ and $3 \mathrm{~b}$ reveals a reduction in the number of the attractive estates $(-3)$. This performance is explained by the loss of attractiveness suffered by some existing estates which were simulated as unqualified in scenario $3 \mathrm{~b}$. Thus, they become less competitive when compared with the advanced estates that will be provided in the future. Results also suggest that the new estates only make sense if inserted in a broader strategy of provision of qualified and competitive estates in order to respond to the requirements of contemporary enterprises. Besides, results also show that the existing estates should be framed in that larger strategy, otherwise these will become less attractive in the future.

Table 3. Main results obtained with the simulation

\begin{tabular}{|l|l|l|l|l|}
\hline \multirow{2}{*}{ Indicators } & Scenario 1 & Scenario 2 & \multicolumn{2}{|l|}{ Scenario 3 } \\
\cline { 4 - 5 } & 3a & 3b \\
\hline $\begin{array}{l}\text { Number of attractive } \\
\text { estates }\end{array}$ & 24 & 50 & 33 & 30 \\
\hline $\begin{array}{l}\text { Number of } \\
\text { unattractive estates }\end{array}$ & 55 & 29 & 53 & 56 \\
\hline $\begin{array}{l}\text { Number of } \\
\text { unoccupied plots }\end{array}$ & 404 & 113 & 723 & 500 \\
\hline $\begin{array}{l}\text { Number of } \\
\text { relocated enterprises }\end{array}$ & 235 & 526 & 694 & 917 \\
\hline
\end{tabular}

The results obtained with the simulation of scenario 2 showed that 29 estates remain unattractive even after being qualified. This is related with the extremely low levels or, in some cases, with the total lack of basic facilities and amenities in those estates. The unattractive profile is often related with the questionable location defined for these estates, which restricts the accessibility and the facilities/amenities coverage. Thus, the industrial estates with minimum conditions become attractive when submitted to a qualification; the poorest remain unattractive even if upgraded. These unattractive estates will hardly play an important role in the Quadrilátero context, being more suitable for encourage the economic development at a local level. To turn these estates attractive, larger investments would be required to overcome the debilities related with their location. Further, municipalities with more industrial estates scattered around the territory exhibit low efficiency in the simulated policies, because dispersion causes a worse level of accessibility and a lower coverage of facilities and amenities. These findings highlight the importance of accurately planning the industrial estates in order to fully accomplish the economic, territorial and environmental requirements for which they were promoted and to avoid additional costs with their qualification in the future. Thus, the results validate the hypothesis 4, that is, the promotion of dispersed industrial estates with low levels of qualification is an inefficient policy to attract enterprises.

The verification of the four hypotheses described above and, particularly, the validation of the last one, means that the paradigm of arbitrarily supplying industrial estates, without criteria of territorial coherence and without advanced levels of qualification should be rethought by municipalities. Policies, to be sustainable and effective, should be properly planned and discussed within the municipality and in 
articulation with the neighbours. In an urban network, such the Quadrilátero, strengthening the municipal coordination of the policies is vital to achieve a global pattern of development.

\section{Conclusions}

Planning industrial estates accurately is an important issue since it determines the territorial and the entrepreneurial competitiveness. The use of appropriate tools is vital to ensure that industrial estates are planned in a more efficient way. This article describes an agent-based model that was developed as a tool for planning a set of industrial estates located in four municipalities. Agent-based simulation is a tool with growing application in the planning domain, because it allows dynamic and individual interactions among several territorial entities in a bottom up approach, highlighting macro patterns that arise from the individual interactions.

The model was geographically explicit and used the enterprises as agents able to assess the industrial estates' attractiveness. The attractiveness was defined by four parameters: facilities, amenities, accessibility and the cost of the land. The industrial estates were represented by patches (cells in which the environment is divided) that contain the data related with the attractiveness. Enterprises could move to another estate when they find a suitable location (the process involves an upgrade of their locative situation). The relocation process encompasses criteria related with the size, the territorial situation of the enterprises and how close or far they are from suitable estates. The impact of the policies in the estates' attractiveness was assessed by three scenarios and four hypotheses. Policies were distinguished by the level of municipal coordination under which they were implemented and by the type of intervention considered.

In the model, the diffused enterprises with bad locative position had the purpose of finding a new location in an industrial estate. The new location would find an upgrade in relation to their original place. The relocation process was concluded when an enterprise would find an industrial estate with vacant plots with a minimum level of attractiveness. In the model, the attractiveness of the industrial estates can be described as their capacity to attract new enterprises.

The adoption of a coordinated policy of qualification was found to be the most effective policy to strengthen the attractiveness of industrial estates. It was in this scenario that more industrial estates became attractive, more enterprises were relocated and more vacant plots were occupied. Despite the general positive effect, the adoption of a coordinated policy of qualification can produce different impacts in a local/municipal scale, as some industrial estates remain unattractive to enterprises. The simulation showed that the estates with the worst locations and with low coverage of facilities and amenities remain repulsive for enterprises even if they are subject to an upgrade. Furthermore, the results also indicated that the promotion of diffused and unqualified industrial estates is an inefficient policy to attract enterprises.

The authors believe that these conclusions can be an important contribution to guide the planning policies addressed to industrial estates for enhancing territorial and entrepreneurial competitiveness. 
Acknowledgment. The authors would like to thank the Portuguese Foundation for

Science and Technology for funding this research (SFRH/BD/48567/2008 grant).

\section{References}

[1] Khan, A.: A system for microsimulating business establishments: analysis, design and results (PhD Thesis), University of Calgary, Calgary (2002)

[2] Maoh, H., Kanaroglou, P.: Agent-based firmographic models: a simulation framework for the city of Hamilton. In: Proc. Second International Colloquium on the Behavioural Foundations of Integrated Land-use and Transportation Models: Frameworks, Models and Applications, Toronto (June 2005)

[3] Levy, S., Martens, K., Heijden, R.: An agent-based model of transport and land use policy coordination between municipalities. In: Proc. Bijdrage aan Het Colloquium Vervoersplanologisch Speurwerk, Antwerpen (November 2011)

[4] Gilbert, N.: Agent-based models, quantitative applications in the social sciences. Sage Publications (2008)

[5] Crooks, A.: Using geo-spatial agent-based models for studying cities. Working Paper Series (Paper 160). Centre for Advanced Spatial Analysis, UCL, London (2010)

[6] Witlox, F., Timmermans, H.: MATISSE: a knowledge-based system for industrial site selection and evaluation. Computers, Environment and Urban Systems 24(1), 23-43 (2000)

[7] Timmermans, H.: The saga of integrated land use-transport modelling: how many more dreams before we wake up? In: Axhausen, K. (ed.) Moving Through Nets: The Physical and Social Dimensions of Travel, pp. 219-248. Elsevier, Oxford (2003)

[8] Devisch, O., Timmermans, H., Arentze, T., Borgers, A.: Towards a generic multi-agent engine for the simulation of spatial behavioural processes. In: Van Leeuwen, J.P., Timmermans, H. (eds.) Recent Advantages in Design \& Decision Support Systems in Architecture and Urban Planning, pp. 145-160. Kluwer Academic Publishers, Dordrecht (2004)

[9] Bowman, J.: A Review of the literature on the application and development of land use models. ARC Modelling Assistance and Support. Atlanta Regional Commission (2006)

[10] Zhao, F., Chung, S., Shaw, S., Xin, X.: Modelling the interactions between land use and transportation investments using spatiotemporal analysis tools, Lehman Center for Transportation Research, Miami (2003)

[11] Torrens, P.: Cellular automata and multi-agent systems as planning support tools. In: Geertman, S., Stillwell, J. (eds.) Planning Support Systems in Practise, pp. 205-222. Springer, London (2003)

[12] Robertson, D.: Agent-based models to manage the complex. In: Richardson, K. (ed.) Managing Organizational Complexity: Philosophy, Theory, and Application, vol. 24, pp. 417-430. Age Publishing (2005)

[13] Brown, D., Riolo, R., Robinson, D., North, M., Rand, W.: Spatial process and data models: toward integration of agent-based models and GIS. Journal of Geographical Systems 7, 25-47 (2005)

[14] Arentze, T., Timmermans, H.: Multi-agent models of spatial cognition, learning and complex choice behaviour in urban environments. In: Portugali, J. (ed.) Complex Artificial Environments, pp. 181-200. Springer, Heidelberg (2007)

[15] Matthews, R., Gilbert, N., Roach, A., Polhill, J., Gotts, N.: Agent-based land-use models: a review of applications. Landscape Ecology 22, 1447-1459 (2007) 
[16] Kim, D., Batty, M.: Modelling urban growth: an agent-based microeconomic approach to urban dynamics and spatial policy simulation. Working Paper Series, vol. 165. Centre for Advanced Spatial Analysis (UCL), London (2011)

[17] Brown, D., Robinson, D.: Effects of heterogeneity in residential preferences on an agent based model of urban sprawl. Ecology and Society 11(1), 46 (2006)

[18] Diappi, L., Bolchi, P.: Smith's rent gap theory and local real estate dynamics: a multiagent model. Computers, Environment and Urban Systems 32, 6-18 (2008)

[19] Crooks, A., Castle, C., Batty, M.: Key challenges in agent-based modelling for geospatial simulation. Computers, Environment and Urban Systems 32, 417-430 (2008)

[20] Singh, A., Vainchtein, D., Weiss, H.: Limit sets for natural extensions of Schelling's segregation model. Commun. Nonlinear Sci. Numer. Simulat. 16, 2822-2831 (2011)

[21] Campo, S.: Developing the land use and transportation integrated modelling framework for Lisbon Metropolitan Area (LUTIA-LX). In: Proc. 11th International Conference on Computers in Urban Planning and Urban Management (CUPUM), Hong-Kong (2009)

[22] Miller, E., Hunt, J., Abraham, J.: Microsimulating urban systems. Computers, Environment and Urban Systems (28), 9-44 (2004)

[23] Ettema, D., Kor, J., Timmermans, H., Bakema, A.: PUMA: Multi-agent modelling of urban systems. In: Proc. 45th Congress of the European Regional Science Association, Amsterdam (August 2005)

[24] Sanders, L.: Les modèles agent en géographie urbaine. In: Amblard, F., Phan, D. (eds.) Modélisation et Simulation Multi-Agents, Applications Pour les Sciences de L'homme et de La Société, pp. 151-168. Hermes Science Publications (2006)

[25] Moeckel, R., Spiekermann, K., Schürmann, C., Wegener, M.: Microsimulation of land use. International Journal of Urban Sciences 7(1), 14-31 (2003)

[26] Squazzoni, F., Boero, R.: Economic performance, inter-firm relations and local institutional engineering in a computational prototype of industrial districts. Journal of Artificial Societies and Social Simulation 5(1) (2002)

[27] Fioretti, G.: Agent-based models of industrial clusters and districts. In: Tavidze, A. (ed.) Progress in Economics Research, vol. IX, ch. VIII, pp. 125-142 (2006)

[28] Albino, V., Carbonara, N., Giannoccaro, I.: Coordination mechanisms based on cooperation and competition within Industrial Districts: an agent-based computational approach. Journal of Artificial Societies and Social Simulation 6(4) (2003)

[29] Giardini, F., Tosto, G., Conte, R.: A model for simulating reputation dynamics in industrial districts. Simulation Modelling Practice and Theory (16), 231-241 (2008)

[30] Albino, V., Carbonara, N., Giannoccaro, I.: Innovation in industrial districts: an agent based simulation model. International Journal of Production Economics (104), 30-45 (2006)

[31] Kumar, S., Kockelman, K.: Tracking the size, location and interactions of businesses: microsimulation of firm behaviour in Austin, Texas. In: Proc. 87th Annual Meeting of the Transportation Research Board, Washington (January 2008)

[32] Wissen, L.: A micro-simulation model of enterprises: applications of concepts of the demography of the firm. Papers in Regional Science 79(2), 111-134 (2000)

[33] De Bok, M.: Infrastructure and firm dynamics: a micro-simulation approach. PhD Thesis, Delft University of Technology, Delft (2007)

[34] Otter, H., Veen, A., Vriend, H.: ABLOoM: location behaviour, spatial patterns, and agent based modelling. Journal of Artificial Societies and Social Simulation 4(4) (2001)

[35] Manzato, G., Arentze, T., Timmermans, H., Ettema, D.: A support system that delineates location-choice sets for enterprises seeking office space. Applied GIS 6(1), 1-17 (2010) 
[36] Leal, A.: Modelação do sistema rodoviário na perspectiva do conflito emergente. MSc Thesis, ISCTE, Lisboa (2009)

[37] SP - Statistics Portugal, Integrated Business Accounts System, Unpublished data base, INE (2011)

[38] Bodenmann, B., Axhausen, K.: Synthesis report on the state of the art on firmographics. Institute for Transport Planning and Systems, ETH, Zurich (2010)

[39] Ramos, R., Mendes, J.: Avaliação da aptidão do solo para localização industrial: o caso de Valença. Engenharia Civil (10), 7-29 (2001)

[40] SP - Statistics Portugal, Census 2011, INE, Lisbon (2012)

[41] Barbot, C.: Industrial determinants of entry and survival: the case of Ave. Working paper 111. FEP, Porto (2001) 